\title{
Tomasz Odzimek
}

Czestochowa University of Technology

e-mail: tomasz.odzimek@wz.pcz.pl

ORCID: 0000-0002-2497-2811

\section{QUALITY OF MANAGEMENT OF COOPERATION OF SCIENCE-BUSINESS-ADMINISTRATION IN POLISH ACADEMIC CITIES}

\section{JAKOŚĆ ZARZĄDZANIA WSPÓŁPRACĄ NAUKI, BIZNESU I ADMINISTRACJI W POLSKICH MIASTACH AKADEMICKICH}

DOI: $10.15611 / \mathrm{pn} .2019 .6 .16$

JEL Classification: O3

\begin{abstract}
Summary: The paper describes the problems of a knowledge-based economy and the creation of new knowledge and technology as a result of cooperation between science, business and local administration. These entities, working together, form the so-called triple helix of science, business and administration. The key issue is the process of managing the triple helix by universities and the local administration, and therefore public entities. Therefore the research aim was to determine the quality of management of collaboration of science, business and administration in Polish academic cities by local entities of the public sector. In this area, a survey was conducted in 20 large academic cities of higher education institutions, city councils and local innovation centres that coordinate the triple helix. The respondents were the entities of city halls, universities and innovation centres and were examined using a questionnaire. The final conclusion was preceded by a comprehensive presentation of the quality of management, including all four management functions.
\end{abstract}

Keywords: triple helix, quality of management of science-business-administration cooperation.

Streszczenie: W artykule opisano problemy gospodarki opartej na wiedzy oraz tworzenie nowej wiedzy i technologii w wyniku współpracy nauki, biznesu i administracji lokalnej. Te podmioty, współpracując ze sobą, tworzą tak zwaną potrójną helisę nauki, biznesu i administracji. Kluczową kwestią jest proces zarządzania potrójną helisą przez uniwersytety i administrację lokalną, a zatem podmioty publiczne. Dlatego celem badań było określenie jakości zarządzania współpracą nauki, biznesu i administracji w polskich miastach akademickich przez lokalne podmioty sektora publicznego. W tym obszarze przeprowadzono badania w 20 dużych miastach akademickich w szkołach wyższych, urzędach miast i lokalnych ośrodkach innowacji koordynujących potrójną helisę. Respondenci z urzędów miasta, uniwersytetów 
i centrów innowacji zostali poddani badaniom za pomocą kwestionariusza. Ostateczny wniosek został poprzedzony kompleksową prezentacją jakości zarządzania, w tym wszystkich czterech funkcji zarządzania.

Słowa kluczowe: potrójna helisa, jakość zarządzania współpracą nauki z biznesem i administracją.

\section{Introduction}

One of the most important conditions conducive to economic development is building an innovative economy. Innovation is considered to be the primary driving force of progress and prosperity. Consequently, significant effort is put in developing new technological knowledge, new process technologies and new products [Volberda et al. 2013, p. 2]. The process of innovation is at the core of the Schumpeterian view of economic change whereby successful "new combinations" - new products, processes, organisations, markets and sources of inputs - are introduced, leading to new economic activities [Bogliacino, Pianta 2012, p. 652].

The share of knowledge and information in the manufacturing process is becoming more and more important in this area, hence we are talking more and more about a knowledge-based economy (KBE).

Its role and importance to contemporary processes of development is emphasized by the fact that nearly two-thirds of the economic growth in developed countries is connected with the implementation of innovation. Innovativeness of the economy is a requirement resulting from the postulate which functions in the global economy i.e. efficiency. Efficiency results from many actions in the socioeconomic area, both from the functioning of enterprises within the economy but also from the functioning of mutual correlations in society.

In turn, one of the factors influencing the growth of innovativeness of the economy is the effective cooperation of science and business. In the aspect of the local economy, the participation of local authorities as the initiator and coordinator of cooperation between business and science sectors is also important. Amidst the steadily increasing integration of the world's economies, certain regions have received close attention due to their capacity for innovation and their favourable economic development. It has been demonstrated that R\&D intensity, innovation activity, and living standards vary more across regions than across nation states [Lundberg 2013, p. 211].

Considerations about the process of management of the triple helix cooperation by local public sector entities in the context of the impact of such cooperation on the innovation of the local economy was the main scientific problem. The author focused on local public sector entities that coordinate cooperation in urban areas, i.e. local government and local universities.

The following section of the article will present the relationship between the functioning of the research and development area and the impact on innovation in the 
economy. In relation to the local economy, we present the issue of cooperation within the so-called a triple helix, whose existence contributes to strengthening the innovation of the local economy. The primary factors here are the relationships between the entities involved in the cooperation of the triple helix and the quality of the management process of such cooperation.

The research aim of the article is to present the results of research on the management process in Polish academic cities. The research results relate to the quality of the local cooperation management process aimed at strengthening the regional or local economy innovation. The research consisted of analyzing the management process according to the management functions. The implementation of these functions affects the quality of the management process.

\section{The issue of a triple-helix science-business-administration in relation to an innovative economy}

The modern economy is an economy based on knowledge and ideas, in which the key factor of prosperity and economic growth is the superior knowledge capitalization. This is why today knowledge is considered to be the driving force of economic growth, productivity growth and a resource that can offer a sustainable competitive advantage. For this reason in the present we can see a great interest for knowledge economy, knowledge, and information and technology and their role in the economic growth [Tocan 2012, pp.199-200].

The key components of a knowledge economy include a greater reliance on intellectual capabilities than on physical inputs or natural resources, combined with efforts to integrate improvements in every stage of the production process, from the R\&D lab to the factory floor to the interface with customers. These changes are reflected in the increasing relative share of the gross domestic product that is attributable to "intangible" capital [Powell, Snellman 2004, pp. 199-202].

Institutions and the institutional environment play a key role in developing a knowledge economy, hence they do matter. Thus conscious efforts must be made to establish new and appropriate institutions, and to change and strengthen existing institutions to support the process towards a knowledge-based economy [Schiliro 2012, pp. 2-3].

Analysis of the literature concerning the competitiveness and innovativeness of enterprises leads to the conclusion that one of the most important areas of gaining competitive advantage is the area of research and development. Enterprises can improve the level of innovativeness both through internal R\&D activities and collaboration with scientific and research centres. The collaboration between science and enterprises with the participation of the administration is termed in the literature a triple helix [Odzimek 2019, pp. 163-164].

The triple helix of university-industry-government interactions is a universal model for the development of a knowledge-based society, through innovation and 
entrepreneurship. It draws from the innovative practice of the Massachusetts Institute of Technology (MIT) with industry and government in inventing a regional renewal strategy in early 20th-century New England. Parallel experiences were identified in "Silicon Valley", where Stanford University works together with industry and government. The triple helix is identified as the secret of such innovative regions [Etzkowitz, Zhou 2017, p. 5]

The "triple helix" is a spiral model of innovation that captures multiple reciprocal relationships at different points in the process of knowledge capitalization. Bilateral relations between government and university, academia and industry and government and industry have expanded into triadic relationships among the spheres, especially at regional level. Academic-industry-government relations are emerging from different institutional starting points in various parts of the world, but for the common purpose of stimulating knowledge-based economic development. Older economic development strategies, whether based primarily on the industrial sector as in the US or the governmental sector as in Latin America, are being supplemented, if not replaced, by knowledge-based economic development strategies, drawing upon resources from the three spheres [Etzkowitz 2002, p. 2].

Existing contributions on university-industry-government-society relationships are extremely useful to understand the drivers and processes of innovation in different countries. However, they mostly focus on the demand side, for example on the implementation of innovation policies via structural arrangements. The supply side of the story - the agency of knowledge producers not only in academia, industry, but also government and society - has to some extent been overlooked. Even though universities are understood as playing a crucial role in innovation, we know very little about the role of key actors who influence and change institutional arrangements in and around universities, e.g. by lobbying governmental actors to change funding regimes and regulation, by engaging in community interaction with civil society or by creating nascent firms and platforms for exchange between various actors in student or academic entrepreneurship [Leišytè, Fochler 2018, p. 2].

From the standpoint of the activities of local administration, with one of its objectives being improved innovativeness in the region, the important factors are the control role and monitoring activity of the collaboration between science and business in the area of the effect of this collaboration on the innovativeness of the local economy. Control should concern the activities undertaken by the local administration, represented by the appropriate entities appointed to cooperate with the areas of science and economy.

Furthermore, scientific centres perform the function of the institutional actor in regional networks. This role consists in direct or indirect cooperation with universities in the innovative process that includes management of the process of creating the innovation for the sector of enterprises. The results of the activities of universities can be reflected not only in the generation of innovations to meet enterprises' expectations, but also in the education of future leaders of small and global enterprises. 
Therefore the functioning of the areas of science and business is more concurrent than would result from at least the definitional discrepancies concerning the overriding goals of functioning, such as generating profit. There are many examples of universities which use the principles which were previously used only by enterprises, such as entrepreneurship and effectiveness of operation [Olechnicka, Wojnar 2008, p. 28].

In a knowledge-based economy, the role of universities and local authorities in collaboration with enterprises has become so critical that the activities of both representatives of the public sector are based on many aspects of this collaboration using the principles dedicated previously only to the sector of enterprises. One of these principles is efficiency and entrepreneurship, which are postulated by the model of new public management (NPM). The innovativeness of this management model consists in the adaptation of the methods and techniques of management used in the private sector to the conditions of management of public organizations. In the new public management, public administration functions in close relation with the market economy in a manner close to the managerial approach. With this approach, public entities such as local authorities and universities take into consideration such assumptions as performance orientation, implementation of market mechanisms, consumer orientation, concentration of attention on management rather than on direct providing services, deregulation, providing conditions for employees' initiative, reduction in costs of providing services, extending managerial roles oriented towards public services, flexibility orientation, innovativeness, entrepreneurship, and apoliticism [Supernat 2003, pp. 26-30]. According to the originators of the concept, this approach can ensure good management, efficiency and effectiveness of the public organization [Zalewski 2005, p. 66].

\section{Management of cooperation of triple helix in light of the author's own study}

Management is universal in character. The principles and techniques of management are equally applicable in the fields of business, education, military, government and hospitals. There is enough disagreement among management scholars on the classification of managerial functions. Newman and Summer recognize only four functions, namely, organizing, planning, leading and controlling. Henri Fayol identifies five functions of management, planning, organizing, commanding, coordinating and controlling. The four common functions of management include planning, organizing, leading and controlling [Schraeder et al. 2014, pp. 52-53]. It should be added that the leading function is also called motivating as a significant part of leadership.

As previously presented, the motive of the article and the scientific problem was the process of cooperation management, carried out by local public sector entities in the context of the impact of such cooperation on the innovation of the local economy. The author focused on searching for answers to the question about the quality of 
management implemented by local public sector entities that coordinate cooperation in the area of cities, i.e. local government and local universities.

For the purpose of researching the quality of management, the following four were designated as the functions of a management: planning organizing, motivating and controlling.

With regard to the above investigations concerning the functioning of the triple helix, the author conducted in 2018 a survey in 20 Polish academic cities. Due to the analysed model of new public management, the survey was focused on the activity of universities and local authorities concerning their collaboration with the sector of enterprises. The examinations were preceded by the question of whether and to what degree, local universities and local authorities manage the local collaboration of the triple helix as an active user.

This research is a continuation of the research conducted in 2013 concerning the same subject area. Therefore the aim of the study was to compare the results of these two studies and to show the differences in the quality of management of local cooperation between universities, innovation centres and local authorities within the triple helix. While continuing the research, the author intended to show the process of management of cooperation over a period of five years against the background of a dynamically developing Polish economy, where such mutual bonds of cooperation are still being built and the effects of its activities are still at an unsatisfactory level. A comparison of the results of this research can be an important guide for many local networks.

The respondents were the entities of city halls, universities and innovation centres. The study examined 80 entities that participated in managing the collaboration in 20 big academic cities in Poland. The respondents were the representatives of town halls, universities and innovation centres who, within the performed work, are responsible for collaboration between the institution and other entities that participate in collaboration.

The research tools used to survey was the questionnaire via e-mail. The survey included questions about particular management functions. The respondents could choose one or more answers. The answers concerned questions about the activities carried out within planning, organizing, motivating and controlling, performed as part of the triple helix cooperation management process.

The area of the study was the following big cities ${ }^{1}$ :

Warsaw, Kraków, Wrocław, Łódź, Poznań, Gdańsk, Katowice, Gliwice, Opole, Kielce, Toruń, Rzeszów, Lublin, Bielsko-Biała, Szczecin, Radom, Białystok, Zielona Góra, Częstochowa, Olsztyn.

Following the analysis of individual functions of the management process, we summarized all the management functions:

${ }^{1}$ According to the source data from the Central Statistical Office of Poland, big cities were those with over 100,000 residents, medium-sized cities from 20,000 to 100,000 residents and towns were locations with fewer than 20,000 residents.

The Central Statistical Office of Poland, Regional and Environmental Surveys Division, Statistical Office in Poznań, Urban Statistics Centre, Cities in Figures, Poznań 2011, p. 1. 
- planning,

- organizing,

- motivating,

- controlling.

\subsection{Quality of management of triple helix cooperation in a holistic approach}

The results allowed for the formulation of the answers to the question about the progress of the process of collaboration management in all the cities studied (Figure 1). As results from the survey, the process of collaboration management in local authorities, universities and enterprises is achieved to a various degree by local entities of the public sector that coordinate the collaboration.

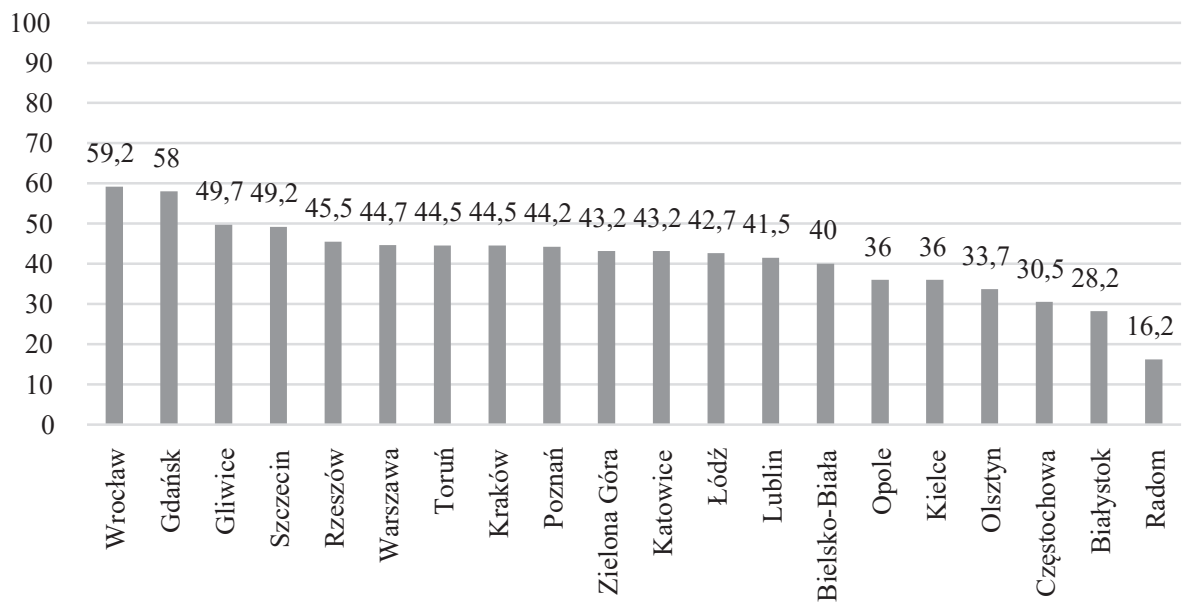

Fig. 1. Level of all management functions in 2018 in the cities studied in percentage terms

Source: author's own study based on the research.

In the case of 18 cities, the level of the activities did not exceed half of the possible to achieved. Only two cities exceeded this threshold, Wroclaw and Gdansk.

Furthermore, in twelve cities the entities were involved in the management process at the level from $40 \%$ to $50 \%$ of activities that can be performed, namely Gliwice, Szczecin, Rzeszów, Warszawa, Toruń, Kraków, Poznań, Zielona Góra, Katowice, Łódź, Lublin, Bielsko Biała.

Another group of cities with the result ranging from $30 \%$ to $40 \%$ included Opole, Kielce, Olsztyn, Częstochowa, Białystok.

The last two places are taken by Białystok and Radom, respectively. It should be emphasized that if the result for Białystok is very similar to the previous group, i.e. a little short of $30 \%$, the last place, with the result standing out from the rest, is unequivocally taken by Radom. 
The results allowed to formulate an answer to the question about the degree of implementation of the cooperation management process in all the examined cities. The research shows that the management process of the cooperation of local authorities, universities and enterprises by local public sector entities coordinating the cooperation is carried out to varying degrees.

Analysis of all management functions in the area of twenty Polish cities, which provide the picture of the implementation of the process of managing the collaboration between local authorities, universities and enterprises, revealed some issues that should be highlighted.

Firstly, considering the four management functions by forming the whole management process, it should be stated that the management process is implemented in all cities, however, to a varying degree.

Secondly, according to the management pattern quoted in the literature, there are no real reasons to admit to any of the examined cities a model of managing of triple helix innovation cooperation. There is no city where the coordinating entities carried out all the possible activities. With regard to the theoretical assumptions, it can be stated that cooperation is effectively managed only in a few cities.

Thirdly, it turned out that only in two of the 20 cities surveyed, the entities participating in the cooperation carried out more than $50 \%$ of the possible activities to plan, organize, motivate and control.

The survey conducted by the author showed that there is a big problem with the implementation of the idea of cooperation of innovation triple helix in Poland. It remains a socioeconomic domain which has just begun to develop and is at the initial stage of development compared to the most developed countries in the world. For this reason, a city with more than $50 \%$ of the possible activities deserves a very good grade. The leaders here are Wrocław and Gdańsk, and Radom was the worst in terms of cooperation management process.

\subsection{Quality of management of triple helix cooperation in terms of management functions}

A key aspect of the functioning of the triple helix of administration-science-business is to compare planned activities and those performed as control activities. Control is a very important issue because this function determines whether planning and execution is appropriate and correlated with each other or detached from reality. Furthermore, it is also important whether the entities monitor the functioning of the cooperation, whether financial resources are distributed effectively, whether there are any reports on the functioning of the collaboration, whether individuals who manage this collaboration see its drawbacks and whether they enforce the intended plans. Equally important is the aspect of adequate motivation to implement the planned actions. The use of appropriate incentives contributes to a greater involvement of cooperation participants on the part of public entities, which in turn reduces potential 
drawbacks and weaknesses resulting from the audit. It follows from the above that a smoothly functioning cooperation requires that each of the discussed functions is performed at least at a good level.

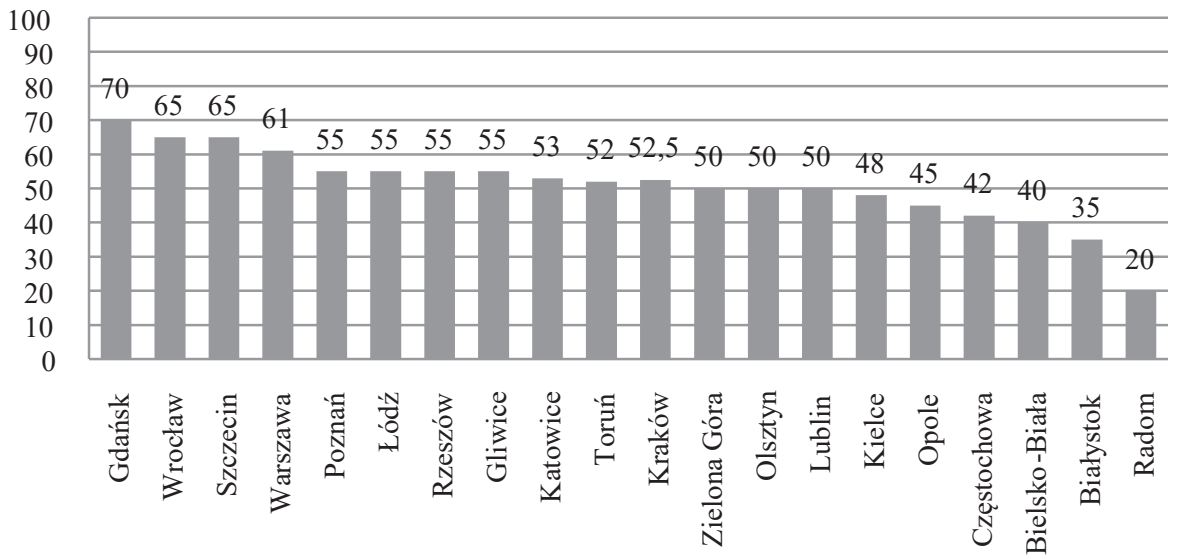

Fig. 2. Results of the survey concerning the level of the planning function in collaboration in percentage terms Source: authors own study based on the research.

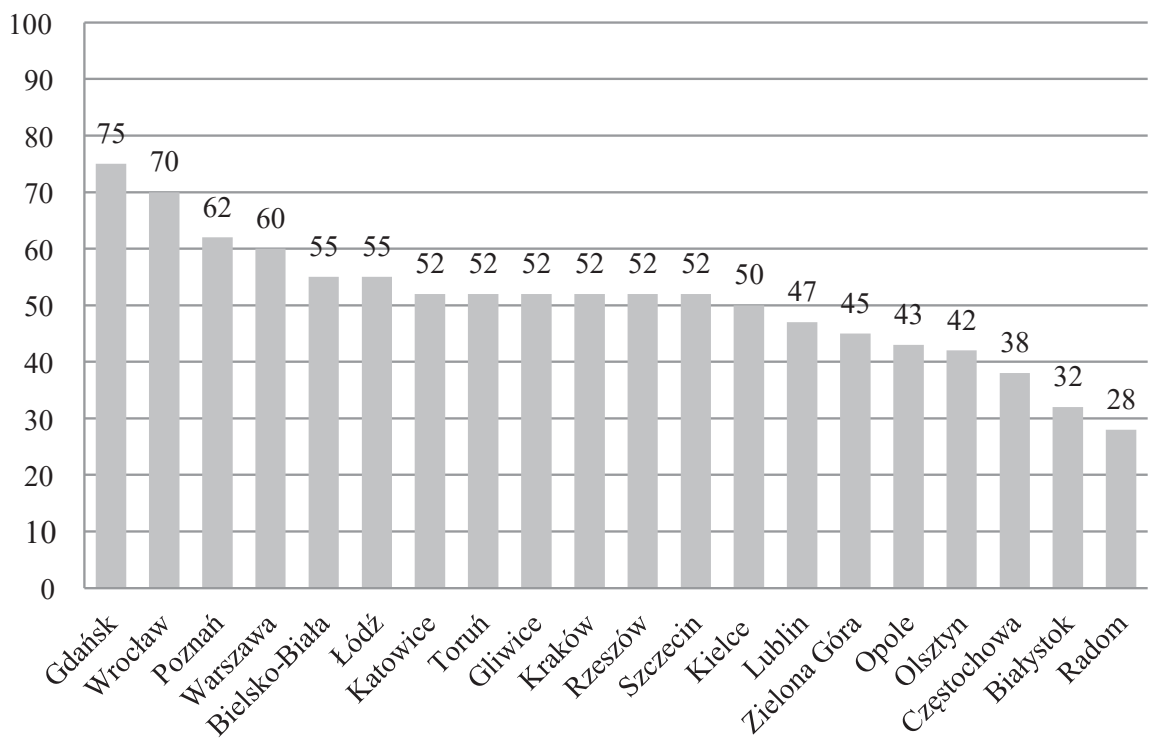

Fig. 3. Results of the survey concerning the level of the organization function in collaboration in percentage terms

Source: authors own study based on the research. 
The detailed analysis of the individual functions should start with the planning and organization activities. As can be seen from Figures 2 and 3 below, planning and organizing triple helix projects takes place in most cities at a good to medium level. Two cities can be distinguished in which this activity is at a very high level, namely Wrocław and Gdańsk.

The overall conclusion is that in two thirds of cases, public sector entities are sufficiently active. At the same time, a third of all the entities studied, both in the area of planning and performance, do not show high activity. The intensity of their actions can be evaluated as medium and low.

Analysis of the motivational function reveals a large percentage decrease in the level of motivational activities compared to planning and organization, as shown in Figure 4. Motivation most often occurs at a medium and low level. In the twenty cities surveyed, more than half of all possible activities are carried out in only one city (Wrocław). For comparison, in the case of the planning function, 11 cities were above the threshold of $50 \%$ of indications, whereas in the case of the organizing function, 12 cities exceeded this threshold.

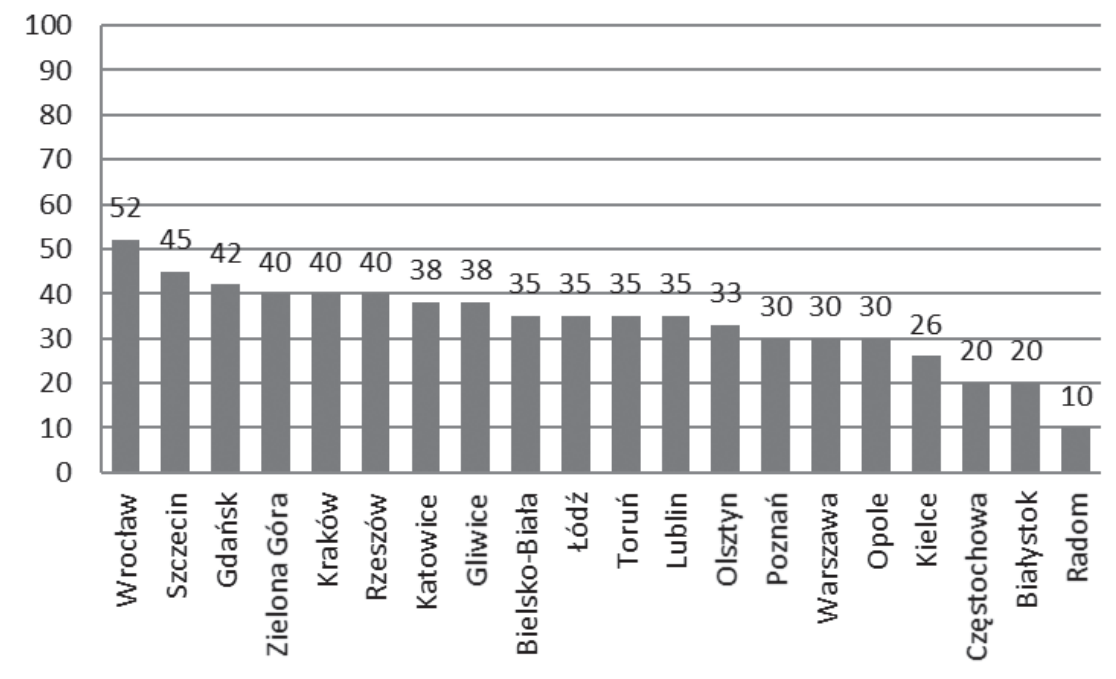

Fig. 4. Results of the survey concerning the level of the motivation function in collaboration in percentage terms

Source: authors own study based on the research.

In seven cities the entities that coordinate cooperation took motivational actions that did not exceed $30 \%$ of those feasible, which suggests that the managers of these entities are not aware of the important role of building proper motivation. Financial motivation, in particular, is used by only a few entities.

From the standpoint of the measurement of the efficiency of the actions, the determinant factor is their verification through control. The level of the control function is presented in Figure 5 below. There is a significant difference in the level of control 
activities compared to planning and organization, i.e. a significantly smaller level of control activities than those planned to be performed.

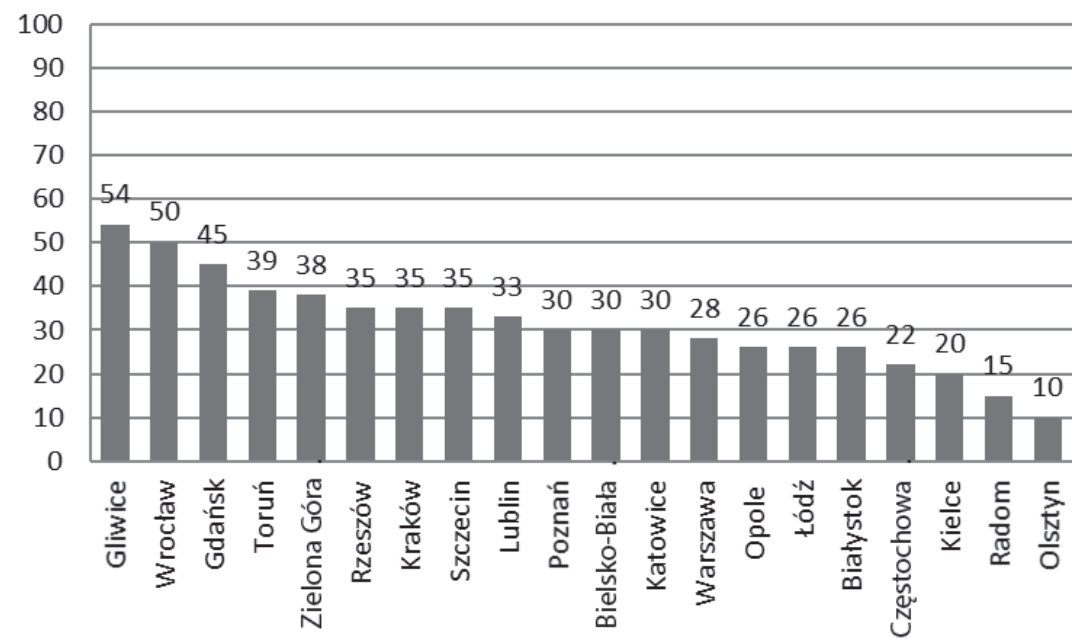

Fig. 5. Results of the survey concerning the level of the control function in collaboration in percentage terms

Source: authors own study based on the research.

An in-depth analysis of the control function shows that it is performed at a moderately good level only in two cities, Gliwice with $54 \%$ of the intensity of activities, and Wrocław with 50\%.

The most numerous group of cities (seven) are those with an average level of advancement, and the same number of cities had a low level of advancement. At the end of the classification there are three cities in which the control of triple helix activities occurs at a very low level not to reach more than $20 \%$ of the possible control activities, namely Kielce, Radom and Olsztyn, where control is only theoretical.

The following conclusion can be formulated based on the survey: the public cooperating entities do not attach much importance to the process of controlling their activities and rarely attempt to monitor the achievement of the aims adopted in the development strategies. Many control activities remain in the area of their planning or insignificant performance. In most of the cases, planning of control activities is not translated into the area of real activities and therefore the control function in most of the cities studied is performed to an insignificant degree.

\section{Conclusions}

The functioning of cooperation between science, business and administration has already become well-established in socio-economic reality, but there is still a major 
problem with the implementation of its idea. Significant deficiencies remain present and not everything is in line with the definition of the process of this cooperation.

The study showed that there are significant shortcomings in the public sector entities managing the triple helix activities in the coordination of joint ventures, from the moment the objective is set to the moment it is achieved. While the entities cope very well with planning and organizing mutual cooperation, the stage of controlling the quality and effectiveness of these activities is at a low level. The same applies to the small number of motivating activities and, importantly, the very small percentage of financial motivation activities, which is very important from the point of view of new public management principles.

In the cities studied, the system of control over the implemented objectives and methods is functioning poorly, despite the identified planning and organization activities. There is a clear discrepancy regarding the quality between the activities that form cooperation on a daily basis and the activities aimed to control the implementation of its objectives, assumptions and priorities. Unfortunately the same applies to motivating to actions within the cooperation, which also makes it very difficult to achieve the objectives of the triple helix in the cities studied.

It is therefore recommended to increase the coordination of the joint works of the actors involved in the triple helix cooperation. A desirable step would be to appoint a helix leader, who on the one hand would be given more authority to enforce the activity of entities and on the other hand, could control the cooperation more as a manager, in line with the assumptions of new public management. The need to increase motivational activities should be also emphasized, especially the introduction of the principles of remuneration for the achievement of cooperation objectives and rules concerning a greater contribution of profit from the process of the commercialization of new technologies.

The aforementioned leader should have controlling powers in the process of monitoring the functioning of the cooperation in order to better verify the assumed objectives in the short and long term.

\section{Bibliography}

Bogliacino F., Pianta M., 2012, Profits, $R \& D$ and Innovation: A Model and a Test, Industrial and Corporate Change, 22(3).

Etzkowitz H., 2002, The Triple Helix of University-Industry-Government Implications for Policy and Evaluation, Institutet för studier av utbildning och forskning, Working paper, 11.

Etzkowitz H., Zhou Ch., 2017, The Triple Helix University-Industry-Government Innovation and Entrepreneurship, London.

Harvey D., 1989, From managerialism to entrepreneurialism: The transformation in Urban governance in late capitalism, Geografiska Annaler, 71B. .

Leišytė L., Fochler M., 2018, Topical collection of the Triple Helix Journal: Agents of change in university-industry-government-society relationship, Triple Helix, 5:10, Springer, https://link. springer.com/content/pdf/10.1186\%2Fs40604-018-0056-6.pdf (29.04.2019). 
Lundberg H., 2013, Triple Helix in practice: The key role of boundary spanners, European Journal of Innovation Management, vol. 16 No. 2 pp. 211-226, https://www.researchgate. net/publication/256081783_Triple_Helix_in_practice_The_key_role_of_boundary_spanners (4.10.2019).

Odzimek T., 2019, Innovation safety management by shaping the law on non-practising entities (patent trolls) in the USA and EU, System Safety: Human - Technical Facility - Environment, DeGruyter Sciendo, CzoTO, vol. 1, pp. 163-164.

Olechnicka A., Wojnar K.., 2008, Rola wyższych uczelni w regionie, [in:] Markowski T., Drzazga D., Rola wyższych uczelni w rozwoju społeczno-gospodarczym i przestrzennym miast, PAN Warszawa.

Powell W., Snellman K., 2004, The knowledge economy, Annual Review of Sociology, 30, pp. 199-202.

Schiliro D., Knowledge-based economies and the institutional environment, Munich Personal RePEc, MPRA Paper, no. 37138, Munich 2012, pp. 2-3, https://mpra.ub.uni-muenchen.de/37138/1/ MPRA_paper_37138.pdf (29.04.2019).

Schraeder M., Self D., Jordan M., Portis R., 2014, The functions of management as mechanisms for fostering interpersonal trust, Advances in Business Research, vol. 5, pp. 52-53.

Supernat J., 2003, Administracja publiczna w świetle koncepcji New Public Management, Administracja publiczna. Studia Krajowe i Międzynarodowe. Zeszyty Naukowe Wyższej Szkoły Administracji Publicznej w Białymstoku, nr 2, Białystok, pp. 26-30.

Tocan M.C., 2012, Knowledge Based Economy Assessment, Journal of Knowledge Management, Economics and Information Technology, issue 5, pp. 199-200.

Volberda H.W., van den Bosch, Heij F.A.J., 2013, Management Innovation: Management as Fertile Ground for Innovation, European Management Review, vol. 10, issue 1, Special Issue Management Innovation.

Zalewski A., 2005, Reformy sektora publicznego $w$ duchu nowego zarządzania publicznego, [w:] Zalewski A. (red.), Nowe zarządzanie publiczne w polskim samorzadzie terytorialnym, Wydawnictwo SGH, Warszawa. 